\title{
1. Public law and economics: a necessary encounter
}

There is more than one cosmos in the universe of 'Law'. This study examines the relationship between two of them: public law and economic analysis of law - two worlds destined to meet (section 1), especially today, at a time when public law struggles to provide adequate responses to modern challenges (section 2).

\section{TWO WORLDS, NOT SO FAR APART}

\subsection{Public Law and Economic Analysis}

The first cosmos, that of public law, is quite familiar. In Europe, this is a legal branch with Franco-German but also British origins and a presence of more than two centuries. ${ }^{1}$ It deals with the specific way in which law governs the actions of bodies exercising public power and intervening unilaterally in our lives, from the parliament to a municipal authority issuing building licences. It studies the fundamental institutions and norms of a legal system (constitutional law) and their implementation by the administration (administrative law). Its DNA is composed of two fundamental concepts: democracy and freedom. It leads to a system in which The People is the sovereign player, and acts through elected officials, without violating the equality and the fundamental liberties of every individual. Democratic liberalism relies on the rule of law. According to this concept, the legal norms adopted by the representatives of the people define the framework of action for all public bodies to serve the 'common good' (general interest) and to safeguard the rights protected by the legal order. A key pillar of the rule of law is the principle of legality; the duty of the administration to respect such legal norms and to abide by the fundamental commandments of the Constitution. Public law is the law of the Demos, governing the way in which its institutions fulfil the various functions attributed to the State; it, therefore, covers a wide spectrum of goals, including

1 Von Bogdandy et al. 2017; Von Bogdandy/Bast 2010; Elliott et al. 2018. For a historical overview, Sordi 2010; Aguilera-Barchet 2015. 
law enforcement, economic and social regulation, environmental protection or even providing services such as education or healthcare.

The second cosmos is rather unexplored and controversial in Europe. Economic analysis of law $^{2}$ started to take shape after the Second World War, with the US at its forefront. Within six decades, it had developed into a key methodology for studying legal institutions. It approaches law through the principles, findings and methods of micro-economics, which is the science that perceives human action as a sum of (more or less) rational choices - choices made for satisfying subjective needs in an optimal manner in circumstances of freedom and scarcity of resources. Rational choice theory dates back to the thinking of Aristotle, Jeremy Bentham and John Stuart Mill. ${ }^{3}$ It focuses on rationality in decision-making, while at the same time surveying the limitations and pitfalls of human reasoning. In the legal context, economic analysis comprehends the law as an institution created to remedy any failures in human behaviour. It examines whether legal institutions perform this particular function; whether they are effective or, even better, efficient. ${ }^{4}$

\section{2 'Deontology' versus 'Ontology'}

These two worlds differ substantially as to their methodology. Public law departs from a deontological starting point. It deals with how human behaviour should be. Its approach is purely normative. On the exact opposite side, economic theory has ontological ${ }^{5}$ foundations. It examines real life through empirical research ${ }^{6}$ and approaches all situations as they actually are. This positive analysis - purely pragmatic, not value-oriented - is then used for normative conclusions; to assess whether human behaviour, an institution, or the law itself functions 'well' or 'badly'. However, the starting point remains positive.

This difference is of paramount importance. Choosing a deontological or an ontological perspective means using a completely different lens to see things. Deontology risks creating a distorted view of reality by aiming for perhaps

2 Mercuro/Medema 2006; Parisi/Rowley 2005; Mackaay 2000; Mackaay/ Rousseau 2008; Shavell 2004; Ogus 2004b. See Chapter 3, section 2.

3 For the philosophical origins of rational choice and economic analysis of law, see Posner 1979; Bix 2018 and Boettke/Piano 2019.

4 All these issues will be further examined in Chapter 2.

5 Both terms, deontology and ontology, come from Ancient Greek. Ućov (deon) means what it should be. $O v$ (on) is the opposite; it refers to what really exists. The two correspond to the methodological distinction between normative and positive analysis; to what Germans call 'Sollen' and 'Sein'. For a similar distinction in the field of public law, Lindseth $2017 \mathrm{~b}$.

6 Landes 2003. 
utopian ideals. Conversely, ontology may lead to a fatalistic or even cynical approach; it risks omitting the desire to improve conditions of life.

I will try to better explain the above through two examples, especially selected to upset the reader. The first refers to the mandatory minimum wage as a means to protect workers. The second relates to the reduction of crime rates in the name of public order. On both issues, jurists would argue according to their 'libertarian' or 'conservative', 'left-wing' or 'right-wing' preferences. They would create a subjective, if not virtual, reality based on their respective values, depending on whether their positions are for or against the increase of minimum wages and for or against enforcing stricter criminal punishments. Some will invoke the principle of the welfare State, concluding that the higher the statutory minimum wage, the greater the warranted protection. Others will demand that more power and more resources be granted to law enforcement, and a zero-tolerance justice system, by referring to public order as a major component of the general interest.

Economic analysis sheds light on facts that may not have even crossed our minds. An increase in the minimum wage does not provide greater protection to all employees. It only helps those who will retain their jobs despite the elevated labour costs. The latter make potential employers reluctant to hire new personnel and may lead to unemployment, especially among young people. Empirical and quantitative evidence leaves no doubt as to this. Instead of safeguarding, labour law guaranties might undermine the right to employment! ${ }^{7}$

If such a finding comes as a shock to a 'left-wing' audience, imagine the reaction of the 'conservatives' to the following story. In the 1990s, some US states experienced a sharp drop in crime. Much ink was spilled seeking potential explanations for this development. An empirical study using economic analysis tools (statistics and data process) came up with a surprising answer: crime reduction was observed only two decades after the states in question legalised abortions; the study revealed a clear causal link between these two facts! ${ }^{8}$ The avoidance of unwanted pregnancies constitutes a much better means of reducing crime than the police force or draconian laws. ${ }^{9}$ One can only imagine the response of a conservative audience expressing their discontent at high crime rates should someone suggest: 'well, then, you should legalise abortion...'.

${ }^{7}$ For the correlation between excessive increase of minimum wages and higher unemployment rates, see Mackaay/Rousseau 2008.2; Friedman/Friedman 1990; Card/ Krueger 1994; Becker 1996; Kennan 1998; Fahn 2017.

8 Donohue/Levitt 2001, 2008.

9 Many Southern US states, in which until recently abortion was prohibited, continued to have higher crime rates, despite greater policing and the imposition of stricter sentences, capital punishment included. 
Those examples teach us an important lesson. Regardless of their preferences, law scholars should shake off certain normative myths. This applies particularly to jurists specialising in public law, who are more prone to the risks of value-driven misconceptions. They deal with the most 'value-oriented' legal text, that is, the Constitution. Excessive idealism is omnipresent in public law. Constitutional metaphysics create a virtual reality: a presumption that State authorities ideally and faithfully serve the values described in the fundamental text. To get back on track with reality, public law needs to be treated with tools that focus on facts and not only on ideal objectives. This method is the economic analysis of law, which can approach any legal problem from a value-neutral perspective. ${ }^{10}$ In the above two examples, economic analysis does not dictate choices. It merely explains the actual consequences stemming from the introduction of specific legal rules. Economic analysis provides information with which we can decide whether consequences are desirable or not.

The importance of examining public law from an economic analysis perspective lies precisely in the methodological differences between the two fields. ${ }^{11}$ By using an economic viewpoint, we may test, complement, verify or correct our normative positions. According to Calabresi and Melamed, this method helps us to perceive 'another view of the Cathedral', as did Monet by painting several aspects of the Cathedral in Rouen, France. ${ }^{12}$ It helps us to capture in our legal canvas an additional aspect of our research field; of our own Cathedral, which is none other than the Demos.

And yet, such a valuable body of knowledge is partially ignored by those tackling issues of public law. This negative stance is all the more astonishing when we take into consideration the historical origins of those two worlds.

\subsection{An 'Upsetting' Affinity}

Economic theory and public law are siblings; both are the offspring of the eighteenth century's democratic liberalism. ${ }^{13}$ The demands for political freedom and democracy were formulated simultaneously with the quest for open markets: Adam Smith complemented John Locke, and vice versa. Liberalism, as an economic system, is associated with the 'invisible hand' of the market. As a political system, it is linked to representative democracy. These two aspects of liberalism rely on the same institutional mechanics; on a common decision-making process diffused among individuals, each

Zamir/Medina 2010.

Ogus 2004b, 2010.

12 Calabresi/Melamed 1972: 'this article is meant to be only one of Monet's paintings of the Cathedral at Rouen. To understand the Cathedral, one must see all of them.'

13 Mashaw 1989. 
acting freely as homo economicus and homo politicus. Liberalism operates on individual intentions, which are expressed either in private transactions or through voting. There is a structural similarity between free markets and western democracies. They use the 'egoistic' rationality of transacting parties and voters to organise both the Agora and the Demos. It is not a coincidence that both scientific fields evolved in tandem, focusing on the advantages and weaknesses of the free market and of liberal democracy, respectively.

In economic theory, ${ }^{14}$ the idealised image of free markets ('classical economics') was called into question after the second half of the nineteenth century, in two ways. On the one hand, this was done creatively; the market was described as an imperfect system in need of correction. 'Orthodox' or 'heterodox' theories (depending on how far they rely on rational choice theory) progressively put forward the importance of State interventionism to remedy market failures (neoclassical economics, Keynesianism, institutional economics). On the other hand, subversive methods were used to cast doubt on a free market, rejecting it in favour of a centrally organised economy (Marxism, fascism). By the late 1980s, those subversive views had been set aside. Nowadays, the universally prevailing approach to the economy is market-oriented. I call it 'agora-centric', market-oriented, since it puts the market, the Agora, at its centre. Some express an almost blind faith in the market; they identify welfare with profit maximisation and express 'State-phobia' (the so-called neoliberalism of Milton Freedman). Others link welfare to additional social objectives (Ordoliberalismus, social market economy); they still consider public intervention necessary to correct the imperfections of the markets. But they all share the same principle: they pursue welfare mainly through open economic structures.

Public law followed the same trajectory. ${ }^{15}$ After a century of innocent optimism - starting with the liberal revolutions in England, the US and France - the ability of liberal democracy to ensure justice and equity was challenged. Two movements emerged, particularly in Europe. One movement wanted to enrich the liberal State with additional missions, in the name of solidarity and social justice. French and German public law scholars pleaded in favour of enhancing the role of the State, to provide and supervise all services with increased social importance (services publics). These approaches are closely related to the economic theories of Pigou and Keynes on market failures. Another, opposing, movement called for an absolute rejection of liberal democracy: it relied on the same ideologies which, as regards the economy, do not believe in the free

14 For a historical overview of economic theories, see Screpanti/Zamagni 2005; Kincaid/Ross 2009; Backhaus 2012.

15 On the historical evolution of public law, Loughlin 2010; Aguilera-Barchet 2015. 
market (communism, fascism). Ultimately, liberal democracy prevailed, and the growing predominance of a market-oriented economy was seen. In its contemporary form, public law relates to two theoretical trends, as in economics: one demanding 'less Demos' and the other 'a better Demos'.

One would expect that this common voyage of public law and economic theory, spanning almost 250 years, would forge a close relationship. However, public law and economics ended up as strangers, particularly on the eastern side of the Atlantic. Why did this happen? History offers some sort of an explanation. For Europe - Mark Mazower's Dark Continent ${ }^{16}$ - it was imperative to escape reality and put values first after half a century of violence. ${ }^{17}$ Having suffered two World Wars, Europe was obliged to envision and define how society should be rebuilt so as to serve higher human ideals, and not the darkness of totalitarianism. ${ }^{18}$

\subsection{Refuting the Myths that Kept Those Worlds Apart in Europe}

In Europe, economic analysis of law is the victim of a triple misunderstanding. It has been connected, first, with the US legal system; second, with State-phobic, neoliberal theories; and third, with Anglo-Saxon common law. These three 'myths' need to be refuted.

It is true that economic analysis of law flourished primarily in the USA, as of the second half of the twentieth century. ${ }^{19}$ This fact may have various explanations. ${ }^{20}$ It does not mean, however, that such methodology only flourishes

\footnotetext{
16 Mazower 1999.

17 Just think for a moment of how legal studies are structured, even today. A student
} in France, Germany or Italy is taught at school the 'correct' values of moral philosophy before tackling the law. Europeans established a 'humanistic' legal science from which mathematics is almost banished, to exorcise, perhaps, the ghastly serial numbers of concentration camps. In this context, it is not surprising that the affinity between law and economics is downplayed. Mathematics is blamed for having the bad habit of 'putting numbers before people'.

18 The European Convention on Human Rights (ECHR) is the most typical example of serving that purpose.

19 For a historical overview, see the essays in Butler/Klick 2018 and see Chapter 3, section 2.

${ }^{20}$ Even the way in which legal studies are structured seems to play a role. Since admission to American law schools requires a first diploma - usually in political science, economics or international relations - the aspiring jurist is familiar with the inter-disciplinary approach to the legal phenomenon (Posner 1987b). But the deeper reasons lie in the Second World War and its consequences. The USA did not need to rediscover its values, as did Europe. It did not suffer destruction during the war; and so, it did not need State intervention for reconstruction. The Americans abandoned New Deal interventionism and identified their increasing prosperity with the benefits of 
there. It has already been transplanted to Europe ${ }^{21}$ - first, in legal theory: top public law academics in Europe have incorporated economic approaches into their work. ${ }^{22}$ Economic analysis is now taught in most European law schools and applied in legal practice. In the beginning, this was the case only in the UK, the 'least European' legal order of Europe. Since the 1990s, economic analysis has crossed the Channel - though not directly but via Brussels and Luxembourg, the home of EU institutions. ${ }^{23}$ Many EU rules (competition law, impact assessment tools, energy and telecoms regulation) were adopted under the theoretical influence of economic analysis; sometimes, after being imported from the US.

Why is the EU more open to an economic view of public law? Probably because the EU model presents two crucial similarities with that of the US. First, it is by definition market-oriented, 'agora-centric'; it pursues its welfare objectives through the creation of a market. This approach is closer to the American legal order than that of many of its member states. Second, both the EU and the US display an increased difficulty in law-making. Their fundamental rules (EU Treaties; the American Constitution) are almost impossible to amend, due to the number of veto players. Secondary legislation is also difficult and time-consuming to produce. ${ }^{24}$ This deadlock has led the US to transfer an important part of regulatory choices from political to administrative bodies. The latter apply a more technocratic approach and methods originating from economic theory. The EU follows a similar model. The European Commission and its administrative services exercise public policy by technocratic and soft law means, in order to overcome the procedural barriers for the European Council and the European Parliament to issue Regulations and Directives.

Unfortunately, economic analysis is often seen as a threat to traditional public law in Europe - a disease that propagates economic Darwinism against

a free and robust market. As early as the 1950s, they linked law with economic theory. As the 'official' date of birth of modern law and economics, we may refer to that of the publication of the Journal of Law and Economics by the University of Chicago Press in 1958. Two years later, Ronald Coase published in this journal the article 'The Problem of Social Cost', which contains his famous theorem. See Chapter 3, section 1.3.

21 Posner 1997b; Garoupa/Ulen 2016.

22 I refer in this book to the work of Giulio Napolitano, Jean-Bernard Auby, Anthony Ogus, Francesco Parisi, Alberto Alemanno, Boudewijn Bouckaert, Sabino Cassese, Klaus Mathis, Mattias Ruffert, Stefan Voigt, Francesca Bignami, Edoardo Chiti, Paul Craig, Michel Faure, Armin Von Bogdandy, and many others who examine public law issues also under the light of economic analysis.

23 De Poorter et al. 2003.

24 It requires the collaboration of three different and autonomous political players; in the USA, these are the Senate, the Congress and the President; in the EU, the Council, the European Parliament and the Commission. 
the general interest. This aphorism is excessive and unfounded. As we will examine in Chapters 2 and 3, economic analysis does not have just one viewpoint from which to look at the Law and the State. ${ }^{25}$ It encompasses several schools, approaches and offshoots. There are two criteria to classify these schools: a methodological and a substantive one. First is whether the analysis is purely positive, using only neutral, ontological tools, or whether it leads to normative conclusions. Second is whether it promotes a narrow or a broad definition of social welfare. Is welfare limited to purely economic efficiency and profit maximisation (narrow definition), or does it encompass other goals (broad definition)? It is true that some schools of law and economics adopt State-phobic conclusions, in the name of spontaneous transactions. However, there are also others that espouse broader definitions of social welfare, including redistributive equality, justice and sustainability. They acknowledge the role of the State and the need for public intervention without rejecting the free market model. The 'agora-centric' approach is different both from 'State-phobia' and 'agora-phobia', the two extremes which demonise the Demos and the Agora respectively. On the one hand, it does not excessively limit the role of the State, leaving private initiative uncontrolled. On the other, it places the market at the epicentre for serving a broad, socially sensitive definition of the general interest. ${ }^{26}$ Thus, identifying economic analysis of law with neoliberalism is misleading.

In any case, this debate has limited interest for Europe. Even in its EU version, European public law will never become State-phobic. Its constitutional foundations are radically different. The Old Continent (at least, most of it) has elevated solidarity and the welfare State to constitutional principles. ${ }^{27}$ In most of the national Constitutions, free economy must serve the general interest. EU primary law refers to a 'social market economy' system and gives its own, broad definition of European welfare in arts 2 and 3 TEU. ${ }^{28}$

\section{Hylton 2019.}

26 Scandinavian countries are a good example of this model. They have opted for an extensive welfare state and high taxation to ensure funding for it, but also for open markets even for providing services of general economic interest.

27 Which is not the case for the US. Alesina et al. 2001; Sunstein 2005b.

28 European welfare 'is founded on the values of respect for human dignity, freedom, democracy, equality, the rule of law and respect for human rights, including the rights of persons belonging to minorities'; its aim is to create a society 'in which pluralism, non-discrimination, tolerance, justice, solidarity and equality between women and men prevail' and to 'offer its citizens an area of freedom, security and justice without internal frontiers'; it establishes 'an internal market' and 'shall work for the sustainable development of Europe based on balanced economic growth and price stability, a highly competitive social market economy, aiming at full employment and social progress, and a high level of protection and improvement of the quality of the 
There remains one last myth to refute: that economic analysis is appropriate for studying private, not public, law. This misunderstanding is due to its erroneous identification with common law. ${ }^{29}$ The synergies between economic analysis and public law will become more apparent in the pages to follow. They are particularly visible in the field of economic regulation. When EU competition law gives incentives to 'whistle-blowers' for revealing cartels, ${ }^{30}$ it applies one of the major teachings of economic and game theory: the 'prisoner's dilemma'. ${ }^{31}$ Liberalisation of electricity and electronic communications markets - another trend in modern public law - is based on the inefficiencies that economic theory attributes to monopolistic structures. ${ }^{32}$ More broadly, economic analysis is valuable even in issues that are not purely economic. It helps to improve all forms of public decision-making. For example, impact assessment studies and public consultations - both part of the EU legislative procedure $^{33}$ - are two instruments that aim to increase the efficiency of public decisions by reducing the information asymmetry of the regulator ${ }^{34}$ and the risk of the latter being 'captured' ${ }^{35}$ by specific interests.

Economic analysis is more than suitable for examining public law. ${ }^{36}$ Some of its theories, such as the one regarding the tragedy of the commons, ${ }^{37}$ seem more useful in the context of public than of private law. They are imperative for understanding this legal field - all the more so in a globalised world, facing various crises.

environment'; to complement these goals, the EU 'shall promote scientific and technological advance'; 'combat social exclusion and discrimination, and shall promote social justice and protection, equality between women and men, solidarity between generations and protection of the rights of the child'; 'promote economic, social and territorial cohesion, and solidarity among member states'; and 'ensure that Europe's cultural heritage is safeguarded and enhanced'.

29 Common law is a legal system promoting diffused, horizontal resolution of disputes instead of centralised public regulation. De Poorter/Rubin 2017 and Lanneau 2014.

30 See the 'Leniency' rules, namely the 2006 EU Commission Notice on Immunity from fines and reduction of fines in cartel cases (OJ C 298, 8.12.2006, pp.17-22), as amended by the 2015 Communication (OJ C 256, 5.8.2015, p.1-1). Also see Andreangeli 2014; Blum et al. 2008.

31 We will examine this in Chapter 2, section 3.2.1.

32 Chapter 2, section 3.4.1.

33 Chapter 8, section 2.2 and Chapter 8, section 2.3.

34 Chapter 2, section 3.1.1.

35 Chapter 4, section 2.3.2.

36 Napolitano/Abbrescia 2009; Parisi 2001; Miller et al. 2018.

37 Chapter 2, section 3.2.2. 


\section{THE RECENT ADVENTURES OF PUBLIC LAW THROUGH THE LENSES OF ECONOMIC ANALYSIS}

The twenty-first century did not start well for domestic public law, in Europe and elsewhere. In the first prosperous years of the century, its national identity found itself between the hammer of the EU and the anvil of the global arena (section 2.1). In the following years, some of its 'existential' axioms came under fire on several occasions (financial crises, Brexit, immigrational pressures, the coronavirus/COVID-19 pandemic) (section 2.2). These developments open a debate about the role of economic analysis for dealing with the challenges facing public law: angel or demon?

\subsection{A Public Law beyond the State}

\subsubsection{Public law, between Europeanisation and globalisation}

For centuries, public law was linked to dominant States. The restriction of national dominance impacts on it decisively, more than on any other field of law. ${ }^{38}$ In our time, 'public law' is no longer 'the Law of the State', the legal extension of a national 'Res publicum' ${ }^{39}$ It is increasingly shaped on a global scale, beyond the State..$^{40}$ In Europe, it is additionally exposed to the impact of the EU. ${ }^{41}$ The latter has its own legal order, more of a public than of a civil or criminal nature. Yet these two phenomena, 'Europeanisation' and 'globalisation', are hardly similar as regards their consequences.

European law did not come about through a virgin birth. It is the child of 'common constitutional traditions' ${ }^{42}$ and values - an attempt to homogenise continental public law, by using the same institutional and normative foundations. ${ }^{43}$ It evolves the pre-existing national models and replaces the good old Kelsenian pyramid of norms with a more complex geometry: a threefold legal order. ${ }^{44}$ This constitutes a normative system that combines three sets of rules, created (a) at the domestic level (in Athens, Paris or Tallinn), (b) in the seat of

\footnotetext{
38 Especially when this transfer of power is not limited to supranational public institutions but extends to 'hazy' organizations that produce a 'quasi-consensual soft law', such as to global institutions for regulating sports events (Olympic Games, football).

39 See the collective works in Rawlings et al. 2013. On the various facets of sovereignty, Krasner 2009. Regarding the EU, Beck 2019.

40 As Sabino Cassese explains in his book, Oltre lo Stato (Cassese 2006).

$41 \quad$ Ruffert 2007.

42 Bratza 2013; De Witte 2015; Walker 2015; Weatherill 2016.

43 Lindseth 2017a.

44 On EU legal pluralism, see Lindseth 2018.
} 
EU bodies (in Brussels, Strasbourg or Luxembourg) and (c) in the framework of the ECHR institutions (Strasbourg again). It constitutes an enrichment, an extension rather than a distortion of domestic public law. ${ }^{45}$

Far from what was just described, globalisation ${ }^{46}$ is an entirely different phenomenon, both as to what it brings about and as to what it symbolises for public law. If the latter is the child of the eighteenth century's western liberalism, the transfer of economic and decision-making power outside State borders rather reflects something else: the lost face of liberalism. Liberalism places humans first; their rights but also their responsibilities arise from personal choices. The gradual de-personalisation of the economy on a global scale ${ }^{47}$ transposes the centre of gravity from individuals to supranational business structures. ${ }^{48}$ Globalisation is not necessarily a bad thing. It led to a considerable reduction of poverty in the Third World. At the same time, however, it does not always respect what we may call 'the liberal acquis': a specific mixture of norms, fundamental rights and values. The achievements of western democracy concerning labour rights or environmental protection are sometimes seen as obstacles to profit maximisation. Compared to national structures, globalisation suffers from a double deficit, both in values and in institutional guaranties. For the moment, it seems incapable of creating a global rule of law, equivalent to domestic and European ones. ${ }^{49}$ It is even less likely to establish a system of governance featuring sufficient elements of democracy. ${ }^{50}$ On the contrary, the globalised economy loves to question national and EU decision-making mechanisms for not being so 'investment friendly'. But the transfer of strategic choices to supranational fora with poor democratic legitimacy is not without risk. In the absence of democratic processes - which would require a 'universal Demos' - social welfare goals, such as justice, redistribution or sustainability, would be under-represented. ${ }^{51}$

45 On the concept and the process of Europeanisation, see Craig/De Búrca 2011; Brouard et al. 2012. A more historical approach is taken by Pierson 1996 and Gilbert 2012.

46 Osterhammel/Petersson 2009; Yueh 2009; Van Creveld 1999; Aman 2001, 2003; Strauss 2006; Chesterman 2008; Larouche/Cserne 2013; Sand 2013; Varella 2014; Auby 2017; Van Meerhaeghe 2012.

47 A long process, which in corporate law is marked by the prevalence of the Société Anonyme, the non-liability of shareholders, the creation of multinationals and, more recently, the key role of financial institutions and investment funds.

48 Gilpin 2001.

49 Held 1995; Cohen 2012; Scholte 2011.

50 Despite the attempt to 'constitutionalise' global institutions such as the WTO. For such process, Cass 2005.

51 One should consult the rules governing the WTO and its dispute-resolution decisions to confirm the above, especially if a comparison is made with the rules and 
The above remarks should also make us cautious as regards global administrative law (GAL). ${ }^{52}$ This new field is a medley of principles, standards, procedures and dispute-resolution mechanisms, applied in various structures of a transnational and often hybrid (public/private) nature. It aspires to establish a common framework for global governance, typified by transparency, participation and accountability. Despite its undoubted kinship with notions familiar to traditional public law, GAL is nothing more than a clone. Guarantees, such as the right to be heard, legitimate expectations or impartiality upon resolving a dispute, are valuable in all 'beyond the State' circumstances. Yet, they are not enough for substituting the national and the EU legal order. GAL is a 'pseudo-public law'; it does not correspond to a Demos that exists on a global scale. ${ }^{53}$ Having said that, we must acknowledge that GAL is more open to the beneficial influence of economic analysis. It tries to combine 'lawful' with 'efficient' governance. Embracing efficiency gives GAL a competitive advantage against traditional public law.

\subsubsection{Legal orders open to global competition? An inevitable and not necessarily undesirable evolution}

Globalisation exerts pressure on domestic legal orders in another way as well: it makes them compete among themselves. ${ }^{54}$ National sovereignty depends on economic strength, which, in a world of increased mobility, interrelates with the capacity to attract investment. Thus, domestic public law ends up participating in a 'beauty contest' on a range of issues that are important to investors: reduction of red tape, coherent tax policy, security of transactions, independent and state-of-the-art regulation, efficient dispute resolution.

The competitive co-existence of legal systems has become an almost irreversible reality. There is even a market for public law systems. Economic players act as consumers in that market by deciding to which regulatory, tax

case-law of the EU institutions on similar issues. Walker 2001; Stewart/Badin 2011; Wessel/Blockmans 2013.

52 Aman 2001, 2003; Anthony et al. 2011; Chesterman 2008; Chiti/Mattarella 2011; Kingsbury et al. 2005; Krisch 2010; Larouche/Cserne 2013; Sand 2013; Stewart 2005; Strauss 2006; Varella 2014.

53 For the absence even of a European 'Demos', see Weiler 2005.

54 Literally speaking, this is not real 'competition' since public institutions act monopolistically (Chapter 4, section 1.2.4). Nevertheless, national legal systems cannot ignore each other anymore; they act as if they were participating in a global market. On regulatory competition, Ogus 1999; Larouche/Cserne 2013; Sachdeva 2010; Esty/ Géradin 2001; De Poorter/Parisi 2005. For a comparative study of public and administrative law systems, Rose-Ackerman et al. 2017; Saunders 2006; Bell 2006; De Geest/ Van den Bergh 2004; Tushnet 2006; Ruffert 2013; Auby/Perroud 2016; Eisenberg/ Ramello 2016. 
or judicial authority they will choose to submit their activity. The choice is made in terms of ensuring investment returns. National systems with inherent weaknesses - for example, those that involve higher administrative costs - are forced to improve. Comparative public law becomes the arena for a 'natural choice process': the more successful the rules or institutions in place, lowering 'entry barriers' and reducing 'inefficiencies', the more attractive a particular legal order becomes. ${ }^{55}$ This new situation is not without threats. A beauty contest run by private investors risks degenerating into a race to the bottom; it may entail a quest for lower environmental and social protection, for fiscal burdens insufficient to finance the welfare State. In other words, 'attractive' public law may undermine the general interest.

Yet, reality seems to be less dismal. Studies in the field of institutional economics $^{56}$ indicate that 'spoiling' investors does not achieve sustainable growth. The latter depends more on the capability of public authorities to guarantee a framework of stability and rule of law; a framework that cannot be attained by sacrificing the traditional guarantees of public law. National systems that perform well in what we call the 'rule of law' - adherence to legality, safeguarding fundamental rights, social and environmental sustainability, transparent and impartial regulators, attribution of justice within a reasonable timeframe, compliance of public authorities with court decisions - offer the most fertile ground for maximising wealth in the long term. The existence of an open economy is not enough; there must be an appropriate institutional framework so that public authority can intervene correctively in market failures, ensure property rights and observance of contracts, safeguard legitimate expectations, impose the execution of legal norms and court decisions, increase social justice and fight corruption. ${ }^{57}$ Conversely, the absence of such an institutional edifice undermines sustainable growth, since it fails to ensure the necessary background of legal certainty and wealth redistribution. It only favours specific elites, excluding other social and economic forces from the process of production. Such systems lead to a decline which is not merely economic.

To put it simply, investment efficiency, the rule of law and the welfare State are mutually compatible and closely related..$^{58}$ Open markets are directly linked to equally open ('inclusive', according to Acemoglu and Robinson ${ }^{59}$ )

\footnotetext{
55 Daintith 1988; Mattei 1994; Garoupa/Ulen 2016.

56 Acemoglu/Robinson 2012; Landes 1999; North 1990; Olson 1982.

57 This is the reason why economic growth is interrelated with the existence of independent courts: Feld/Voigt 2003.

58 Paul et al. 1997.

59 Acemoglu/Robinson 2012. Even Richard Posner stresses the relationship between equality, wealth and political stability: Posner 1997b.
} 
public institutions. Both are important to bring growth and welfare. In this context, traditional public law remains, even after globalisation, a 'rather good enough' model for organising Demos. There is one condition, however: it must adapt to new challenges and cure its pathologies. This necessity became apparent in times of crisis during the past decade, especially in Europe.

\subsection{Crises in Europe and Elsewhere Reveal an Unpleasant Truth: The Shortcomings of Traditional Public Law}

In 2007, the world faced a financial crisis that first affected the most globalised part of the economy, the banking sector, and continued by creating a chain reaction among other economic fields. ${ }^{60}$ In Europe, the crisis began in 2008. It mostly hit the countries of the South - Portugal, Italy, Greece, Spain (PIGS) and Cyprus - as well as Ireland. For Greece, it officially started on April 2010, when the Greek government requested the IMF's assistance; it took almost ten years for things to improve.

A few years later, united Europe faced new challenges. First, it lost one of its member states. What started as a referendum in 2016 which few expected to actually take place resulted in an even less expected (at least initially) outcome: Great Britain leaving the EU as of 31 January 2020. Some years before that (and still), the EU had proved itself unable to forge a coherent, efficient and, most of all, common stance towards the humanitarian and social crises created by the vast number of asylum seekers and immigrants crowding at its borders. The States of the European South induced major consequences while the EU organs failed to establish workable policies both within EU borders and outside them (by helping to reduce the problem at its source in Asia and Africa).

2020 has been a bad year globally for another reason: coronavirus/ COVID-19, a disease that started in China before spreading to all continents. Many countries were severely hit and had to take unprecedented confinement measures that, apart from restricting fundamental freedoms, considerably affected the economy. As these lines are written, the nightmare is far from over: even if the world manages to come up with an efficient medical response to the virus, the pandemic's social and economic symptoms are expected to last.

In the brave new world of Europeanisation and globalisation, crises do not emerge or function as purely domestic problems. They take the form of a disease both imported and exported, endemic but also epidemic. The inability to cure them internally puts public structures, society and the economy to a test

60 Backé et al. 2010. 
beyond national borders. I will try to explain how these crises are related to traditional public law (section 2.2.1) and to its inherent pathologies (section 2.2.2).

\subsubsection{The connection between economic and other crises with institutional failures and public law}

One factor common to all of the difficulties that have emerged in the twenty-first century is that they relate to the defective exercise of public authority. They reveal the absence of a public law system able to prevent and to redress them.

On a global level, the failings of the financial sector ${ }^{61}$ indicated that its expansion was not accompanied by a public supervision mechanism suitable for controlling it. The increased mobility of capital and its ability to evolve or mutate forms (derivatives, structured bonds, sub-prime loans) rendered national regulation impossible or irrelevant. Globalisation proved incapable of managing the failures of a sector that it nourished more than any other. Instead, it merely confirmed its institutional deficit. Such a deficit proved also crucial regarding the shortcomings in dealing with the humanitarian crises due to massive immigration from less developed countries or war zones to safer destinations, and, recently, the coronavirus pandemic. There are no efficient control mechanisms with transboundary or global range capable to intervene for ensuring order and welfare where needed. International institutions - the World Health Organization, for example - do not possess the power or the means to act promptly and to bypass the opportunistic behaviours of dominant States at the global arena; they can be easily set aside or even captured by the most powerful nations.

On a European level, the problem is set on a different basis. The EU suffers from a defective institutional and constitutional design. ${ }^{62}$ Regarding the economy, it opted for a monetary union with a hard currency and strict budgetary discipline though a lack of appropriate central supervision mechanisms. ${ }^{63}$ In periods of crisis, EU institutions do not have the means or the procedures to take timely and decisive corrective action. The Treaties do not provide for such tools, since the European integration process did not succeed (until now) in making the EU a sovereign federation; in other terms, in transforming the

\footnotetext{
61 Aronson 2009; Wagner 2012.

62 For EU constitutional and institutional issues, see the collection of articles and contributions in Eger/Schäfer 2012; Barber et al. 2019; Garben et al. 2019. On the problems that were revealed by the euro crisis see the contributions in Joerges/Glinski 2014; Fabbrini et al. 2015; Dawson et al. 2015; Papadopoulou et al. 2017; Hofmann et al. 2019 and Bignami 2020.

${ }^{63}$ Backhaus 1999a; Eichengreen 2012; James 2012; Ruffert 2020; Markakis 2020.
} 
EU into a real Demos. Consequently, the problems afflicting some of the EU's member states are not effectively addressed, despite their impact on the common European interest. There is not a coherent model for shaping EU public decisions that genuinely promote such interest rather than the national agenda of the member states' representatives at the EU organs. This serious defect in exercising public authority can be easily detected in all of the recent occasions where the EU failed to react promptly and struggled to reach various compromises (Brexit, immigration, restarting the economy after coronavirus). As will be explained in the following chapters, the EU is a public law system extremely vulnerable to principal-agent problems mainly arising from the opportunism of its sovereign members.

On a domestic level, there is a close connection between institutional deficiencies, attributed to public law, and the various economic, social or other failures. Western European States historically rely on continental public law system for organising their Demos. However, their structures proved inadequate to avert recent crises. In some cases, such as Greece or Italy, these structures may have played a crucial role in causing them.

The Greek economy did not collapse in 2010 because of the banking system, as was the case in Cyprus or Ireland. The crash resulted from successive deficit budgets, reduced revenue and increased expenditure, which led to an inability to control public loans and national debt. The problems were of an institutional rather than an economic origin. ${ }^{64}$ In theory, Greece has a state-of-the-art model of public law. ${ }^{65}$ Despite all this, it has proven the European champion in the failure of its public institutions. Excessive public borrowing was just the tip of the iceberg. ${ }^{66}$ From the point of view of institutional economics, Greece set

64 It was not the private sector that contaminated the State; quite the opposite. The economy was infected by inefficiencies attributed to public authorities. Those problems proved much harder to confront than those originating from the private sector. A solution, even if painful, was ultimately found in States with ailing banks; for example, Cyprus used public authority to 'haircut' bank deposits and never looked back on the recession again.

65 A modern constitution, parliamentarism, separation of powers, an exhaustive list of fundamental rights, a network of independent authorities and judiciary and an administrative law almost identical to the French model.

${ }^{66}$ Many other factors played their role. Ballooning of the public sector; total lack of measurement of the efficiency of public policies and of providing incentives within administrative structures; increase in public expenditure through rent-seeking and clientelism but also through judicial activism, in the name of the welfare state and social rights; at the same time, the percentage of those social costs that was really directed to those in need still remains one of the lowest in Europe; a phobic, if not inimical, attitude towards the markets, through high barriers to entry and high administrative costs, protectionism, tolerance of various lobbies and elites; high levels of corruption in several fields, including local authorities, State-owned companies and public procurement; 
a negative example of the connection between Demos and welfare: a model of low-quality 'extractive' institutions, ${ }^{67}$ which redistribute wealth in favour of specific elites, in an ongoing, negative-sum game (where wealth available for distribution is reduced while the game lasts). These institutions are incapable of serving growth because they are not sufficiently open and fair. ${ }^{68}$ As long as the system is able to provide some level of growth and redistribution, it maintains a balance. However, this balance is not sustainable. ${ }^{69}$

Italy is in a much better situation than Greece but records many of the same problems attributed to its neighbour. Its institutions are not sufficiently inclusive; political corruption has been historically high, together with rent-seeking by various lobbies; the rule of law has been regularly challenged by organised crime (mafia is an Italian word) for decades. In addition, the gap - cultural and economic - between the northern and the southern parts of the country hinders the coherent functioning of the administrative structures (already underperforming for other reasons), while the country's devolved model of governance increases the cost of political transactions in taking public decisions. All of the above played a role in making Italy the worst affected European country at the beginning of the coronavirus outbreak (spring 2020). ${ }^{70}$ Due to economic austerity and public debt of over 130 per cent, the national healthcare system was underfunded and unprepared to deal with the disease. The various inefficiencies of public institutions, both political and administrative, were responsible for delays in taking and sufficiently supervising confinement measures. Such pathologies of the Italian Demos made things much worse for a country already overexposed to the pandemic for other reasons (Italy was the first European State confronted with the virus, had a high percentage of elderly people, had a dense population, did not have a culture of social distancing, and so on).

poor public planning in various sectors - land uses, tourism, energy - since planning does not leave room for political favours on an ad hoc basis; absence of fiscal and legal certainty, aggravated by the multiplicity of laws, constant regulatory changes, and the systematic failure of the judiciary to ensure timely and effective legal protection.

67 Acemoglu/Robinson 2012.

68 Greece seems to have experienced the problem in the worst possible way. It has fallen into what Aristeidis Hatzis, following Daron Acemoglu, calls a 'middle-income' institutional trap: Hatzis 2018. A similar analysis is made by Keefer/Vlaicu 2008, on the consequences of clientelism in 'low-credibility states'.

69 At the same time, it falls into a status of a 'limbo State': on the one hand, it imperatively needs to be reformed; on the other, those benefiting from the extractive institutions exert pressure to maintain the status quo. It only needs a spark to bring disaster, as happened in Greece in 2010. Hatzis 2018.

70 As of August 2020, Italy remains the continental European country most severely struck by the pandemic, in terms of the number of casualties. 
Returning to the primary subject of our study, public law, the above examples send a worrying message. They set in doubt the ability of public law, especially in its traditional version, to function as a barrier to severe State failures. Public law is a legal system that focuses on preserving legality and seems unconcerned as to whether institutional action is successful. Therefore, it is not in a position to direct public authorities back to the correct course when they have gone astray, and even less so to contribute to their re-design.

These accusations are extremely serious. Unfortunately, they are not unfounded.

\subsubsection{The original sin: public law was not initially created to guarantee an efficient State}

Many years have passed, but we should not forget that first-generation public law was a genuine child of eighteenth-century democratic liberalism. It relies on the assumption that parliaments produce rules that blindly express the will of The People and specify the only 'correct' definition of general interest. The democratic process is the sole prerequisite for providing legitimacy to public action. Judges shall abide by such legitimacy and enjoy only limited powers. Judicial review on the merits of democratically reached, collective choices seems sacrilegious. This public law praises the elected representatives of The People and downgrades the judge to 'la bouche de la Loi', a mouthpiece of the law. It does not care about efficiency in State action, as long as the latter is 'legal'.

Seen in this light, public law relies on a narrow, almost metaphysical view of the legality principle. It identifies what is correct with the lawful exercise of public authority. Legality has two facets. First is a hierarchical one. It imposes respect for the superior rules in the pyramid of law. Those rules reflect the fundamental values of the constitutional order (freedom, solidarity, popular sovereignty, and so on). Second is a procedural one. Legality is identified with the mechanics of representative democracy. Fundamental values are materialised in everyday life via a democratic decision-making process.

This 'legality-oriented' public law serves purely normative objectives: targets reflected in rules and specified by other rules. Those rules are open to a purely 'normative' (not positive) interpretation and implementation. The starting point should not be the problem to be solved, but the norm itself. The 'Law' sets imperatives; administrative action and private behaviour must comply with them, irrespective of how things stand in real life. Such a normative view of legality is evident in the elliptic and imperfect definition of another fundamental concept of public law, that of general interest. This notion ends up having formal/procedural rather than substantive content: general interest is what legality says it is; what the democratic process has decided as such within a constitutional legal order. 
Moreover, traditional public law presents another crucial characteristic. In most countries, including France, Germany or the United Kingdom, it evolved through case-law. Even its current, largely codified form came from judicial rulings reviewing the legality of public action in an attempt to protect the addressees of such action. It is a set of rules and procedures primarily to be used by law scholars - lawyers and judges - in resolving disputes between citizens and public authorities. This explains why it does not focus on the effective use of public authority to pursue the general interest. Judicial review is fragmentary by nature. The 'systemic' efficiency of State institutions cannot be assessed in the context of a specific dispute. This assessment is not even necessary if public law only aims at protecting private individuals against the arbitrariness of the State.

Being 'judicially born' and 'legality oriented', public law could not but be purely 'legalistic' - unfriendly to extra-legal, interdisciplinary approaches of a political, social or economic nature. These approaches are crucial for assessing efficiency in the operation of public institutions, but for centuries they did not find an appropriate space in judicial procedures. The average lawyer or judge did not feel comfortable in using them as interpretative tools, but preferred to sail in the familiar and safer waters of legal dogmatism.

All of the above somehow explain why traditional public law failed to offer the most adequate solutions in the recent times of crisis. It was created to serve legality and to safeguard private interests against public authorities with legal/ judicial means. It was not meant to coherently ensure the proper functioning of public institutions; to create better economic supervisors in Greece before 2010 , or a better healthcare system in Italy in 2020. State failures fly under the radar of the traditional public law if they do not harm specific individual rights. The notions of effectiveness and efficiency occupy a marginal place, to the extent that they are not connected to public law's primary function: the ad hoc protection of the citizen.

\section{WHAT IS ECONOMIC ANALYSIS FOR PUBLIC LAW?}

If not improved and adapted to modern times, traditional public law is not appropriate for remedying institutional inefficiencies in the pursuit of social welfare. In some cases, it may be considered jointly responsible for various problems. It is unable to fight rent-seeking, administrative inertia, clientelism, excessive red tape, disastrous policies and public spending, or other problems of a Demos on the road to perdition.

Even though this criticism is correct, we should avoid exaggerations. It is not public law alone that caused the financial crisis in Greece or increased the number of coronavirus casualties elsewhere in Europe. In any case, countries 
with Anglo-Saxon legal systems, such as the US or the UK, seem to have reacted even worse in dealing with the pandemic; so, it is not only continental public law to blame. To put it simply, traditional public law is not a 'bad' medicine to be totally rejected. It was simply designed to cure a different disease: to protect individuals from the arbitrary use of public power. This therapeutic property remains valuable and irreplaceable, particularly in difficult times.

Having said this, public law must not remain tied to the successes of the past. Since it governs the operation of public institutions, it cannot stay unconcerned with their lack of success. If Demos fails as an institutional model, public law cannot perform its primal mission, to protect the citizens and promote social welfare. When the health or the education system, social security, police or justice are ailing, evoking fundamental rights becomes meaningless.

It is time for public law to evolve and enhance its therapeutic properties, especially in Europe. Economic analysis can be valuable in achieving that end. It is the scientific method that focuses on the definition, the measuring and the pursuit of efficiency for all human actions, including those undertaken by public authorities. It is the methodological tool for transforming traditional public law into something better; into a system that will combine legality and the protection of individuals with the successful and sustainable functioning of public institutions. 